\title{
Femininity as Strategy: A Gendered Perspective on the Farmers' Holiday
}

\author{
LESLIE A. TAYLOR
}

THE FARMERS' HOLIDAY was a captivating event in Iowa history. The farm women and men who participated in the Holiday were trying to solve the crises disrupting their lives. Resentful of low prices, farm people withheld their products in an effort to raise prices. Using a variety of creative tactics to keep their land, they also halted foreclosure actions. Both broad and local studies have described this important movement. ${ }^{1}$ No historical work, however, has addressed women's role in supporting or opposing the Holiday or inquired about their absence. In the existing accounts of the Farmers' Holiday Association, women in general may receive a line or a footnote. More often, Ella Reeve "Mother" Bloor, the Communist party activist who was a prominent organizer in Iowa and Nebraska, receives a comment. ${ }^{2}$

An earlier version of this paper was presented at the Missouri Valley History Conference, March 14-16, 1991 in Omaha, Nebraska. I would like to thank Patricia Cooper, Maureen Howe, Kathy Jellison, Kim Jensen, Alison Kibler, Kim Nielsen, Sharon Wood, and, especially, Linda Kerber, for their support and helpful criticism.

1. The standard account is John Shover, Cornbelt Rebellion: The Farmers' Holiday Association (Urbana, IL, 1965). See also Lowell K. Dyson, "The Farm Holiday Movement" (Ph.D. diss., Columbia University, 1968); idem, Red Harvest: The Communist Party and American Farmers (Lincoln, NE, 1982); and Rodney D. Karr, "Farmer Rebels in Plymouth County, Iowa, 1932-1933," Annals of Iowa 47 (1985), 637-45.

2. William C. Pratt, "Rethinking the Farm Revolt of the 1930's," Great Plains Quarterly 8 (1988), 134-35, recently invited a "rethinking" of these movements that would include the "much neglected topic" of women's involveTHE ANNALS OF IOWA 51 (Winter 1992). (CThe State Historical Society of Iowa, 1992. 
Yet midwestern women did participate in the Farmers' Holiday, both as supporters and as opponents. Women's participation in the movement took two forms: working within the constraints of traditional femininity, women employed their femininity to manipulate the chivalric code; and they used a familiar ideology of traditional gender roles to construct a female consciousness, which served as the basis for organizing a Ladies Auxiliary of the Farmers' Holiday Association.

Women's history scholars who have investigated the style of women's protest actions have devoted their attention to interpreting the particular ways women have acted and the language employed to construct those actions. ${ }^{3}$ These scholars have identified the existence of a chivalric code which positioned men as protectors and women as those to be protected. The code could be bent to allow for women's activity, although those activities would still be constructed as "feminine," and women's relations to men would be highlighted. Newspaper accounts of the Farmers' Holiday protests clearly reveal the existence of such a chivalric code. They also provide valuable information about women's actions designed to manipulate the code while preserving the traditional language of femininity.

The concepts of "female consciousness" and "communal consciousness" have also contributed to our understanding of women's protest, and they, too, apply to the Farmers' Holiday movement. The Iowa women who formed a Ladies Auxiliary

ment. "Students of women's involvement in farm movements on the northern Plains," he argued, "must actively look for references to women and ask questions about them. A substantial amount of information probably is out there; we simply have not hunted for it."

3. On the "feminine" strategy employed in "women's protest," see Amy Swerdlow, "Ladies Day at the Capitol," Feminist Studies 8 (1982), 493-520; Temma Kaplan, "Female Consciousness and Collective Action: The Case of Barcelona, 1910-1918," Signs 7 (1982), 545-66; and Jacquelyn Dowd Hall, "Disorderly Women: Gender and Labor Militancy in the Appalachian South," Journal of American History 73 (1986), 354-82. Hall's work creates a space for understanding "women's distinctive forms of collective action, using language and gesture as points of entry to a culture." The women she studied "belonged to a venerable tradition of 'disorderly women,' women who, in times of political upheaval, embody tensions that are half conscious or only dimly understood." Ruth Milkman, ed., Women, Work and Protest: A Century of U.S. Women's Labor History (New York, 1985), also contains valuable articles on women's protests. 
articulated a consciousness based on agreement with the traditional obligations entailed by a gendered division of labor. They simultaneously defined themselves as a "class organization" because they were farmers. Thus, a "communal consciousness" or solidarity with other farm workers also existed.

Together these concepts suggest the complex ways women negotiated their identification within a grass-roots movement. The women who took part in the Farmers' Holiday movement were not a single monolithic group; nor did all women support the Holiday. The strategies women employed as they participated in the Holiday can inform us about the ways gender relations saturate social movements.

DIFFICULT TIMES for farmers across the Midwest were not new when the Farmers' Holiday began in 1932. Price declines for farm products were already a fact of life in the 1920s. But the sharpest declines did occur in the early 1930s, so farmers who had increased their debt during the prosperous years before and during World War I were vulnerable when the economy crashed in 1929.4

Farm organizations responded vigorously to these crises. During the 1920s the National Farmers Union joined other farm organizations in lobbying for legislative solutions to ease price fluctuations and the loss of markets. The Farmers Union supported the McNary-Haugen Bill, which would have created protective tariffs and forced prices up through government purchasing. The Union also supported the Agricultural Marketing Act of 1929, which created a Federal Farm Board whose task was to stabilize farm prices and create markets through the establishment of large farm cooperative marketing associations. President Coolidge vetoed the McNary-Haugen Bill twice, however, and the government farm boards proved of little help. ${ }^{5}$

Frustrated by the failure of traditional political lobbying efforts, a group of radicals within the Farmers Union began to press for the use of more radical tactics. The radicals were led by John Simpson of Oklahoma, who was elected president of the National Farmers Union in 1930, and Milo Reno, president

4. Shover, Cornbelt Rebellion, 13-16.

5. Ibid., 19. 
of the Iowa Farmers Union and later the founder and president of the Farmers' Holiday Association. At the heart of the radicals' program was the concept of a guaranteed cost of production. According to this concept, the federal government should guarantee that the price farmers received for their products would cover their costs and labor and provide a small profit. Reno and others recognized that this goal could not be achieved by ordinary political lobbying; as early as 1927 Reno had proposed the idea of a withholding action to force prices up. Reno was not able to secure the support of a majority of Farmers Union members for such a strategy, however. ${ }^{6}$

The Iowa Farmers Union was "the organized core that led the cornbelt rebellion," but by itself it could not create the mood necessary for a mass movement. Farmers who might have rejected radical actions in the 1920 s became more receptive to radical tactics as prices plunged, foreclosures increased, and legislative assistance and government plans provided little help. Farmers began to vent their anger in 1931. In Cedar County, Iowa, some farmers refused to allow veterinarians onto their land to test their cows for tuberculosis, a test the farmers considered costly and useless. Farmers mobbed state agents who came onto their land. Only when the National Guard was called in were the herds tested. ${ }^{7}$

A quick downturn in prices also spurred the movement toward a withholding action. The sharpest yearly decline ever recorded for hog prices was in 1932. Corn prices also hit bottom: to receive cost of production for their corn in June 1932, farmers would have had to receive 92 cents per bushel; the prevailing price was just 10 cents per bushel. Foreclosure rates had also increased dramatically. The number of foreclosures in Iowa more than doubled from 1930 to 1931 and nearly doubled again in 1932. In 1933 Iowa's foreclosure rate was the highest in the nation. ${ }^{8}$

6. Ibid., 20-27.

7. Ibid., 31-34.

8. Ibid., 13-16, 39. Iowa farm product prices, value of farmland, outstanding farm mortgage loans, and number of farm foreclosures, 1911-1940, are conveniently tabulated in Patrick B. Bauer, "Farm Mortgagor Relief Legislation During the Great Depression," Annals of Iowa 50 (1989), 24. 
With a number of factors pointing to worse conditions ahead, momentum began to build for a withholding action. Planning meetings were held in Iowa as early as February 1932. In Des Moines on May 3, 1932, two thousand farmers ushered in the Farmers' Holiday Association (FHA) as a national organization. Throughout the summer, announcements for membership drives and organizational meetings for the FHA appeared in newspapers across the Midwest. FHA organizers announced that a withholding action to force prices up to "cost of production" would begin July 4, 1932. No action materialized, however. More than a month later, on August 8, a strike was declared that resulted in some activity in Des Moines. The Holiday withholding action began in earnest on August 11, though, in Sioux City, where dairy farmers began a strike against the J. R. Roberts Dairy Company. ${ }^{9}$

Surprisingly, Holiday actions in Iowa erupted primarily in counties along the western boundary adjacent to the Missouri River, and mostly in relatively prosperous areas, not among the most poor. It appears that Holiday members and leaders were mostly landowners or those who expected to inherit land rather than farm laborers or tenants. Marginally prosperous farm people had the most to lose in a depressed economy. For them, the Holiday program had much appeal. ${ }^{10}$

Yet there were major differences between what Holiday leaders expected and what occurred. FHA leaders had never endorsed picketing or road blockading as tactics, but the protesters used both. Despite the FHA's organizational efforts, the protests that took place in northwest Iowa were spontaneous and sprang from the grass roots, not from the leaders' directives. ${ }^{11}$

Through the remainder of August, barricades of logs, threshing belts studded with nails, and bales of hay blocked roads around Sioux City, Omaha, and Council Bluffs. Pickets forced trucks laden with milk, butter, cream, eggs, cattle, and

9. Shover, Cornbelt Rebellion, 37, 40-43.

10. Ibid., 4-9, Karr, "Farmer Rebels," 641-43. These farmers were presumably male. Neither author mentions women who engaged in Holiday activity.

11. Shover, Cornbelt Rebellion, 41-42. 
hogs to turn around. If their warnings went unheeded, they sometimes dumped or liberated cargo. Within the first week picketing and blockading spread throughout Woodbury County (where Sioux City is located) and into Plymouth and Cherokee counties. Receipts of all farm products dropped markedly in those first days. The Sioux City Journal reported, "The embargo on deliveries of livestock, butter, eggs, milk, and poultry was virtually 100 percent effective." The blockade was so effective that milk had to be imported by rail from Omaha into Sioux City. ${ }^{12}$

FARM WOMEN as well as farm men were on the picket lines from the beginning of the withholding action. ${ }^{13}$ During the first week, the Sioux City Journal declared, "Hundreds of farm men and women placed barricades in roads to prevent produce laden trucks from entering Sioux City." Another headline proclaimed, "Strikers Picket 5 Highways. 1500 Men and Women Patrol Roads; Turn Back 20 Trucks."14

When women were present at a site, the presence of gender on the picket line became visible through a change in the language used to describe the situations. Newspaper reports identified most women as "farm women" or "farm wives" and rarely, if ever, as "farmers." Men, on the other hand, were more generally described as "farmers," "pickets," or "strikers," but never as "farm husbands." The newspaper accounts usually suggested that women on the line were connected to a man through marriage. For example, "Women walked the road with their husbands and some women were reported to have driven cars across the highway to halt the truck operations." 15

12. Sioux City Journal, 20 August 1932; Shover, Cornbelt Rebellion, 41-57. 13. Local Iowa newspapers from Woodbury, Monona, and Harrison counties and the national Farm Holiday paper are the sources that provide evidence of women's activity. I paid careful attention to the precise use of language within these reports in order to interpret assumptions about the meaning of "femininity" and "masculinity" in the 1930s in the United States. I have found no collections of correspondence or journals of specific women activists or formal organizations mentioned in this article.

14. Sioux City Journal, 16 August 1932; Missouri Valley Daily Times-News, 15 August 1932.

15. Missouri Valley Daily Times-News, 15 August 1932. 
Traditional understandings of femininity set limits for the women's actions in support of the protest. They did not seek to upset the chivalric code; instead, they worked within its parameters. For example, women's actions on the line often consisted of nurturing and support. In that capacity, women were again described according to their relations to men. An article on August 17 reported, "Wives, daughters and sweethearts were visiting the pickets and observing the progress of the holiday movement." The next day a picture of women, the first to include women in the Holiday, showed three women serving seven men. Many of the men gazed directly at the camera; the women remained in profile. The caption read, "In order that pickets in the farmer's strike may maintain a constant vigil over the highways leading into the city, farmers' wives, daughters and sweethearts have established free lunch counters along the roadsides and are serving sandwiches, lemonade, coffee and milk." Only one newspaper story referred to women staying at the camps at night, and it too identified women by their marital status. "More than 300 farmers, some of them accompanied by their wives, guarded Half Mile Hill last night." ${ }^{16}$

When the reports did acknowledge women's participation in protest actions, they differentiated between generic strikers and farm women who ostensibly performed the same work. "Strikers ... worked feverishly dragging up heavy logs and chains which were stretched across the road. Farm women tugged at the logs along with their men." The difference in degree of work, between men who "worked feverishly dragging" and women who "tugged" was also demarcated. ${ }^{17}$

During the following two months, mass crowds gathered at open-air organizational meetings, while pickets demonstrated and prohibited access to roads and markets. As the

16. Sioux City Journal, 17, 18 August 1932; Missouri Valley Daily Times-News, 23 August 1932.

17. Missouri Valley Daily Times-News, 16 August 1932. A report from Yankton, South Dakota, in the Sioux City Journal, 28 August 1932, also acknowledged that "Even a woman might do her bit in blockading highways, if permitted." According to the report, "After Sheriff John Dalmann of Cedar county, Neb, destroyed signs and red flags used by farm holiday pickets to stop produce trucks at the south end of the interstate bridge here, one farmer's wife offered her red petticoat as a substitute. The offer was refused and 
strike progressed, the mood shifted from celebration to anger, and sheriffs warned Holiday leaders and pickets not to engage in violence. ${ }^{18}$ Many male pickets were arrested, increasingly for unlawful assembly. A few farm pickets were killed; deputies and truckers were beaten. As the violence increased, local newspapers included no more pastoral pictures of Holiday women and men eating calmly by the roadside, no more references to women serving lunch, accompanying pickets, or residing at camps. The chivalric code may have dictated that the need to protect women exceeded the need for their services. Or it may have been that women needed to labor on the farm while the men continued to monitor the roads. Chores and children remained even while protests raged. ${ }^{19}$

Some women obviously did support the Holiday and worked in various capacities on the picket lines even as their actions were carefully defined in the newspaper articles to emphasize their connections to men or their femininity. Other farm people and transportation workers, who needed to get fattened livestock to market, earn wages, or procure food for their families, tested the strength of the strike. Among those who did not support the Holiday's withholding action were women who employed their femininity strategically to circumvent the blockade.

An article titled "Mother Asserts Pickets Abused Her" reported the story of Mr. and Mrs. George Lebeck, who, with

red lanterns were brought into service." While the language of the report again diminished the significance of the woman's action, the incident may suggest the "erotic undercurrent" of women's protest or the role of fashion play in women's distinctive style of protest, both of which were identified by Jacquelyn Dowd Hall in "Disorderly Women."

18. Sioux City Journal, 23 August 1932.

19. There is evidence that women who supported the Holiday did participate in the huge parade in Sioux City on September 9, 1932, in conjunction with the Governors' Conference. The Sioux City Journal, 10 September 1932, reported that "One of the trucks was driven by a woman and contained only women and babies." Unfortunately, there is no record whether this truck, like the others, was plastered with signs calling for higher prices, a moratorium on debts, or other demands. But the description of these women, in a truck driven by a woman, is striking and hints at female solidarity. It also hints that separatism was employed strategically, and possibly at a women's agenda that so far is unknown. In addition to women driving in the parade, pictures revealed many women watching the parade. 
their child, attempted to take six cans of milk to market to buy food for their family. Mrs. Lebeck alleged she was treated "roughly when she alighted from their auto and began pushing aside heavy timbers." She threatened the pickets with a club if they "molested her." Another newspaper report of the incident noted that pickets "twisted her arm and otherwise abused her and her child when she got out to remove a barricade." The car did get through, but the pickets followed them all the way into Sioux City. The Lebecks drove directly to the sheriff's station, whereupon the four men-all Woodbury County residentswere arrested. ${ }^{20}$

The reports described Mrs. Lebeck's actions in distinctly feminine terms: that she "alights" from the car emphasized her feminine grace; that she "pushes heavy timbers" emphasized the frailty of women who would not be expected to accomplish such a task. Most important, the Lebecks manipulated traditional concepts of femininity and masculinity as a strategy in order to feed their family. One article explained that they had run the blockade at least three times that week, using Mrs. Lebeck to clear the road because they knew that the male pickets would not hurt her. She herself turned to the law to uphold the chivalric code when the pickets refused to honor her protected status.

Women occasionally drove with men and acted as foils to bypass the pickets, but there is at least one recorded incident of a female truck driver, Mrs. E. P. Baack of Craig, Iowa, who successfully drove a truckload of livestock to Sioux City on Sunday, September 4,1932. Pickets ordered her not to return. The next day, however, she did return along with a caravan of fourteen other truck drivers. Two hundred farmers met the caravan near the Woodbury-Plymouth county line and tried to halt its progress. The article reported that Mrs. Baack "escaped injury during the fight Monday morning." Several male truckers did not. ${ }^{21}$

The film documentary, Plowing Up A Storm, reports a similar-perhaps the same-incident. In the film, a farmer

20. Sioux City Journal, 25 August 1932; Missouri Valley Daily Times-News, 24 August 1932; Council Bluffs Nonpareil, 24 August 1932.

21. Sioux City Journal, 6 September 1932. 
who is describing the Holiday movement tells the story of a female trucker who had a load of livestock. Seeing timbers in the road, she accelerated to sixty miles per hour and ran through the blockade. One mile farther down the road, pickets threw a fifteen-gallon drum of gasoline into the road and lit it; she drove through that as well. The narrator recounts, gleefully, that when her tires finally went down, the pickets fixed them and let her through. They figured that anyone who had that much "guts" deserved to get past the blockaded road. ${ }^{22}$

Mrs. Baack was probably one of few women truckers. By working in a gender-segregated field, she was already acting outside of the female norm. Farm women were certainly driving cars, and some drove cars to block trucks on the blockade. They probably drove trucks and farming equipment on the farm, too, but they were not doing it for wages. Running the blockade was a treacherous feat, as pickets, truckers, and passengers (both women and men) were getting hurt. Mrs. Baack's actions illustrate how the code could bend for some women. It is doubtful that a man exhibiting such behavior would have had his tires changed by other men and then allowed to pass through. The men's action in changing Mrs. Baack's tires shows how the chivalric code was upheld while it was simultaneously challenged.

Manipulating the chivalric code did not always allow women to achieve their goal, however. A story from Omaha titled "Woman's Threat Fails to Stir Farm Strikers" explained, "A farm wife threatened to throw herself under the wheels of a farm truck and her husband's tears failed to overcome the determination of farm holiday picketers." Mr. Nelson, described as a manager of a Farmers Union store, "had to get to Omaha to sell his chickens to meet a $\$ 25$ overdraft at the bank." When he was advised to turn around, Mrs. Nelson cried, "What's the use of living anyway? If you don't let us through, I'll throw myself in front of this truck." According to the report, as Mr. Nelson wept, she stepped into the road, and the oncoming truck swerved to avoid her. Despite her action, or perhaps because of her husband's tears, they were not allowed through. ${ }^{23}$

22. Plowing Up a Storm (Lincoln, NE, 1985).

23. Sioux City Journal, 6 September 1932. 
These articles point out some of the complex texture of Holiday activity when gender relations and the use of femininity as strategy are considered. Reading all of these reports together, it is evident that women, perhaps encouraged or supported by their husbands, tried to manipulate the chivalric code. Mrs. Nelson desperately attempted to work the code toward her own end, but unlike the Lebecks, the Nelsons did not succeed. That could be because of timing in the Holiday, or because the Omaha pickets enforced the blockade more rigidly. On the other hand, the nature of their actions may have provoked the different responses. Mrs. Lebeck threatened to hurt the men and physically removed barriers, and Mrs. Baack showed "guts" running over obstacles; Mrs. Nelson threatened suicide. Although she moved in front of the truck, she removed nothing from the road, nor did the pickets remove barricades for her. Furthermore, whereas Mr. Lebeck proceeded to press charges, Mr. Nelson cried. Mr. Nelson's tears, a distinctly unmasculine act, demonstrated desperation.

These reports point out the problematic aspects of the Holiday as well. Nelson's managerial position in a store that was affiliated with the Farmers Union ought to indicate some sympathy for the Holiday. Clearly some farm people whose families were in danger would break the withholding action even for the little money their hogs, corn, or eggs would bring.

Strategies differed between women who supported and opposed the Holiday, and newspaper reports used different language to construct their actions. Those differences are evident in an article about the Minnesota Holiday. The article describes separate actions by two different women on opposite sides of the protest. In October, pickets and blockades quieted down in Iowa. In Minnesota, however, Holiday attempts to block roads began in earnest. At Howard Lake on October 12, 1932, between seven and eight hundred pickets and sympathizers gathered to close off Minneapolis. The "outbreak" that resulted was deemed "the most serious since farmers in several Minnesota counties began picketing." One farmer suffered a fractured skull, and two deputies were wounded. Also, "Mrs. Lee Robasse, farm woman, was bruised. A truck wheel ran over her foot as she attempted to help male pickets prevent unload- 
ing of live stock."24 The article mentioned Mrs. Robasse only because she was injured; no other woman was mentioned, although other women might have been there.

Gender is always present in any action. Yet only when women are present does the language used to construct actions recognize them as gendered; otherwise the actors are presumed to be male. Still, gender influences the way actions are perceived. Thus, the adjective male had to be used to differentiate between pickets. Mrs. Robasse was differentiated further as a helper. As an activist, she sustained an injured foot; as a woman, she "attempted to help male pickets." Usually, the lone verb help would occur, but here she is doubly removed from the action: she was "attempting" to "help." This difference is even more clear when it is contrasted with a line from the following paragraph in the same article: "Some attempted to prevent unloading of live stock." The verb help is noticeably absent when the gender around "some" is not declared.

The same article featured another woman, but one who opposed the Holiday activity. Mrs. Robasse received only a brief line for her injury, but Mrs. Margaret Heldt was granted an interview regarding her actions on October 11 at a road blockade roughly twenty miles from where Mrs. Robasse was injured. The account of the interview began, "Going about her household work on a farm near Eagle Bend, Minn., Wednesday was Mrs. Margaret Heldt, who defied the pickets near Anoka Tuesday night, hammered the toes of a few, and pushed spiked planks and timbers from the highway." Captioned with the indented header "Free For All Fight" in bold type, the article continued,

Mrs. Heldt, 24, and weighing only 110 , modestly refused to say much about what happened, although drivers of a truck fleet she helped through the picket lines gave her most of the credit for their progress. The free-for-all fight was well under way when she came along.

"While my husband and other drivers held off the pickets I removed the planks as quickly as I could," she said. "Then I noticed some of the pickets going toward our trucks to let the live

24. Sioux City Journal, 13 October 1932. 
stock loose. I ran over there and held to the lock, and of course, the men didn't dare strike me."

Mrs. Heldt said she doesn't always accompany her husband, but 'Thought he might need a little help' this time because of the picketing.

Ira Olsen, Wadena farmer, praised Mrs. Heldt highly.

"We got her a hammer," he said, "and when the pickets attempted to stop the trucks she hammered their toes." ${ }^{25}$

Through her use of "and of course," Mrs. Heldt indicated that she was familiar with chivalry. She turned the code around and actually injured men because she knew that she would not be hurt in return. However, her femininity was obviously not lost by that action. She was placed firmly in that context as a small weak female by emphasizing that she weighed "only $110^{\text {" }}$ and that she "modestly refused to say much." Here was a woman who changed the course and the tenor of the protest, who refused to take credit, and who in the end was praised by another man who corroborated her story. She was also aware that this was a special event, that she ordinarily would not be driving with her trucker husband, and that fundamentally she was "helping." Mrs. Heldt was not suffering from "false consciousness"; rather, her own words convey that she exhibited "female consciousness" and a knowledge of the ideology of chivalry and the gendered division of labor within which she operated. While codes of femininity allowed Mrs. Heldt room to act, they simultaneously constrained her, especially as she could not take full responsibility or assume agency for her actions.

Clearly, then, women did participate in the Holiday as both supporters and opponents. Some women built barriers, served food, or patrolled the rural roads of the Midwest during the Holiday's withholding action. Newspaper reports usually defined them in relation to the male participants, and sometimes used language that diminished, or at least constrained, the importance of their actions. Women who did not support the Holiday were also evident during the withholding action. In order to circumvent Holiday goals, they deployed their femi-

25. Ibid. 
ninity strategically. Their actions bent, but did not upset, chivalry or the dominant gender formation. Their actions suggest that while dominant ideologies constrained women's actions, those ideologies were elastic enough to allow for manipulation and agency.

WHILE SOME WOMEN were active on the front lines of the Farmers' Holiday movement, tugging logs in support or hammering toes in opposition, other women supported the Holiday by creating an Iowa Ladies Auxiliary. The strategies they used were not directly at odds with the techniques employed by those out on the roads. They did not upset or even critique traditional femininity and female roles. Instead, auxiliary women used the concept of "female consciousness" to articulate the importance of the Holiday agenda for women.

Female consciousness results when women identify as a group with a particular ideology. According to Temma Kaplan, "Those with female consciousness accept the gender system of their society; indeed, such consciousness emerges from the division of labor by sex, which assigns women the responsibility of preserving life. But, accepting this task, women with female consciousness demand the rights that their obligations entail." Those obligations include providing food, medical care, and shelter for one's community. Auxiliary women also defined themselves as a "class organization" and united themselves with other farmers, including male Holiday activists. Nancy Cott explains, "Women's communal consciousness ought to be explicitly recognized for its role in women's self-assertions, even while those self-assertions are on behalf of the community that women inhabit with their men and children." Both of these identifications allowed women to negotiate a place for themselves as "farm holiday women." ${ }^{26}$

Farm Holiday women were united by their gender, race, nationality, geographical region, agricultural ties, marital status, and sexual orientation. Midwestern newspapers of this time always noted if a person was "Negro," so one can assume

26. Kaplan, "Female Consciousness," 545; Nancy Cott, "What's in a Name? The Limits of 'Social Feminism'; or, Expanding the Vocabulary of Women's History," Journal of American History 76 (1989), 827. 
that others are white, or are perceived as white, unless otherwise noted. Because differences are not highlighted, members of the Ladies Auxiliary may have been more similar than different. ${ }^{27}$ It is not clear whether ethnicity, social status, religious affiliation, kinship ties, or degrees of landholding created fissures in their organization. It is clear, though, that the members' "female consciousness" and the ideological basis of the auxiliary supported the privately owned home and farm, the nuclear family, and a sexual division of labor, and did not fundamentally critique the economic system or a structure of male protection. Their agenda cannot be interpreted as feminist because they did not critique the system of male domination. ${ }^{28}$

The Ladies Auxiliary of the Farmers' Holiday Association of Iowa apparently formed in Shelby County in January 1933. In 1934 "farm holiday women" from several Iowa counties elected the dynamic thirty-eight-year-old Mrs. Edna Jones of Missouri Valley, Iowa, to the office of state president. ${ }^{29}$ As president of the Ladies Auxiliary, Jones regularly contributed a column to the Farm Holiday News. Her views may not represent those of every woman in the auxiliary, but her authoritative position as president and the prominence of her columns suggest that her ideological positions were acceptable to most Holiday members.

Upon her election, Jones's statements received front-page coverage in the Missouri Valley Daily Times-News. She proclaimed, "It is up to the rural mothers to teach their children

27. See Elizabeth Spelman, Inessential Woman: Problems of Exclusion in Feminist Thought (Boston, 1988), for a discussion of how language erases and marks difference.

28. Marjorie Penn Lasky, "Where I Was a Person': The Ladies' Auxiliary in the 1934 Minneapolis Teamsters' Strikes," in Ruth Milkman, ed., Women, Work, and Protest, discusses the conservative ideology underlying most ladies' auxiliaries.

29. Missouri Valley Daily Times-News, 4 January 1934. To my knowledge, this was the first time the term farm holiday women was employed. Mrs. Jones was referred to as and used the byline of "Mrs. Carl N. Jones" throughout her tenure as president. Some of her prominence may have stemmed from the community's acknowledgment of her marital ties to the chairman of the Harrison County Farmers' Holiday Association and her status as a college graduate (see Census of Iowa for 1925), although she herself did not explicitly name either of those distinguishing characteristics in any of her columns. 
how to build that system of economy [sic] justice, as the mothers are the moulders and builders.... The depression will be over when our people have learned enough about the workings of economic force to get into action, correct the present ill workings, and make them work for, and not against us." Jones invoked the idea of "mother" as "educator" of small children. She did not expect those children to overthrow the economic system, however, but to correct it. Jones appealed to women to identify as a group of mothers, and she blamed the economic system for creating the problems they faced, but she did not link the two in a way that would critique the lack of justice. ${ }^{30}$

In another article titled "Where Are We Drifting?" Jones attacked the "socialistic" intervention of the Roosevelt administration and the Agricultural Adjustment Administration (AAA). She also explored the ideological bases upon which the Farmers' Holiday Association and the Ladies Auxiliary drew. Both were loyal to the "original spirit of the American Constitution and God Almighty's laws"; they also rested upon the Declaration of Independence and the Golden Rule. Cloaking the auxiliary in this American tradition provided her with an opportunity to illustrate how protesting was patriotic. It also enabled her to appeal to female consciousness and farm women's common national identity.

American civilization depends upon the American farm home, but when your home life is destroyed all hopes of civilization is [sic] lost. Then just where is the place for that mother or wife within that home? It takes character and confidence to hold society together.

And again I appeal to the rural women through out [sic] Iowa to go forth more determined than ever to organize into a class organization of their own. ${ }^{31}$

Even though Jones demanded that women form themselves into a "class organization," she was not calling for a new system. The term class organization was bandied about regularly in the

30. Missouri Valley Daily Times-News, 4 January 1934.

31. Farm Holiday News, 2 April 1934. 
rhetoric of the Holiday, and Jones was working with that cultural material. The term, however, had never been used to describe any gender specifically, but Jones claimed it for women's purposes.

Similarly, in "Firm Stand for Personal Freedom," Jones ruminated on the ideas of the home, government interference, and women's place. She explicitly demarcated the parameters of the home and farm and women's subservient position to the male head of both. "Let us each, as farm women, look at the man who is head of our home and farm and realize that he knows more about farming than anybody in Washington can tell him." She also questioned her place as a woman to think about these problems. "Perhaps, as a farm woman, I really should think about the separator as I wash the separator and not about those slippery promises to us farm people. According to [the government's] theory, we should cut down mental production and put part of our brain out to permanent pasture, with a fence around it, that wouldn't let an idea get through." Although she concluded that writing and voicing concerns were important, action was still more important. "[Let us] not only pray but join hands with our farm sisters in a united action under our own class organization." 32 . Jones did not situate women as the heads of the home or the farm, yet she saw a need for women to act with other "sisters" as a "class." But not every woman was a "sister."

This primacy of the farm home and women's place in it as well as the limits of "sisterhood" are readily apparent in exchanges between farm women, including some members of the auxiliary, and Eleanor Roosevelt. More broadly, that correspondence shows the parameters of female consciousness and differences between women of different regions and classes. In the March 12, 1934, issue of the Missouri Valley Daily TimesNews, Eleanor Roosevelt was pictured departing via sea plane for Puerto Rico "to study relief and industrial problems." Two weeks later, Jones wrote directly to Roosevelt.

Since you have evidenced a deep interest in the welfare of the women and children of this distant land, we are wondering if

32. Ibid., 10 May 1935. 
you would be so kind as to accept an invitation from the women who compose our organization to come to this great food producing state and learn first hand the trials and heartaches of the farm women.

We should like you to be our guest, the guest of the plain women who toil on the farms..., so that you may go from farm to farm and hear the stories from the lips of those who are actually helping carry the burdens; so that you may personally see and understand our living conditions. ${ }^{33}$

Roosevelt declined the invitation, saying she knew a great deal about Iowa farmers and what they and their wives have had to go through. However, in the July 1934 issue of the Woman's Home Companion, a magazine that featured a monthly column by Roosevelt herself, she commented further on what she knew about the midwestern farmer who lived "on some marginal land who cannot produce enough to feed his family or to nourish his few scrawny head of cattle, whose house has few conveniences, whose barn is much in need of repair, whose children are unkempt and unwashed and miserably dressed. ... His wife is old before her time, she has no medical care, her work is hard and unending and her life drab beyond description. This type of farmer either lives on a rented farm or carries a mortgage on his property so big that he usually loses it in hard times. ${ }^{\text {"34 }}$

Not surprisingly, the editors of the Farm Holiday News reacted negatively to Mrs. Roosevelt's reply, especially her attempt to compare upstate New York apple orchards to acres of corn. The verbal assault on the farm wife sparked heated responses from farm women in letters to Woman's Home Companion and the Farm Holiday News and in several article-length responses that were printed throughout 1934. Roosevelt's harangue could have sparked or cemented female consciousness among some women; she also provided a convenient target for those who wanted to vent their hatred of AAA policy.

33. Ibid., 2 April 1934.

34. Eleanor Roosevelt, "Rural Homes," Woman's Home Companion, July $1934,4$. 
Mrs. Clem Tamisciea of Missouri Valley, Iowa, appropriated Roosevelt's words and used them against her.

If our homes are run down or our children unkept [sic], or miserably dressed, it is not because we don't care, or don't try, to have them otherwise, but because of the ruinously low prices of farm products. ... We know that we are deprived of the things that we might call luxuries but what the rich call absolute necessities. For instance, a very large majority of us are deprived of the convenience of a bathtub. ... How much easier it would be for us to keep up our children's appearances could we only have such a convenience. But it is not luxuries we want or are asking for. All we are asking for is a fair price for our products that we might provide our little ones with the barest necessities of life." ${ }^{35}$

This woman accepted both the traditional gendered division of labor and its resulting obligations. She directed her anger at her diminished ability to carry out her obligations, not at the obligations themselves.

The importance of the home, the need to save it, and the need to protect the women who resided there served as the basis for the Ladies Auxiliary's first known resolution. The eviction of the Woolerys, an Elmore, Minnesota, family comprising a widowed father, his three children, and a male friend, spurred the Ladies Auxiliary to action and made the front page of several issues of the Farm Holiday News. Of course, many other evictions had occurred throughout the 1930s, but in this case forty-five deputies forcibly intruded at six o'clock in the morning; they used tear gas and shot at a fleeing son and his friend. But what made this "one of the most revolting and brutal demonstrations in the long and growing list of farm evictions" was the treatment of the young women. In an attempt to prevent their father from being handcuffed, one daughter, Elsie, grabbed and swung at one of the deputies. Six deputies grabbed her and later her sister Elizabeth and dragged both women down the stairs and out of the house. The article emphasized that all of the "motherless children" had graduated

35. Farm Holiday News, 15 August 1934. See also ibid., 2 July 1934. 
from high school with high honors; in addition, the two women had completed normal school. ${ }^{36}$

Only a short time later, the Ladies Auxiliary of Iowa formulated and adopted a resolution that remains part of the permanent record of the National Farmers' Holiday Association's 1934 annual convention. The resolution provides the first piece of evidence that women attended and participated in national meetings. Unfortunately, no transcript survives to document who sponsored or read the resolution on the floor, whether it provoked any debate, or how many votes it received. The lengthy resolution first summarized the story of the Woolery family and concluded,

We the members of the Ladies Auxiliary of the Farmers' Holiday Association condemn not only the eviction of the farmer, but with all our power do we condemn the cowardly, dastardly, and revolting abuse of these young farm women, and BE IT FURTHER RESOLVED: that we ... call upon farm women everywhere to take whatever steps are necessary to stop such cowardly attacks upon American womanhood and punish those who are responsible and who condone such acts. ${ }^{37}$

Some of the powerful language can be attributed to the threat eviction represented for Iowa farm women. Foreclosures and bankruptcies increased dramatically in Iowa in the early $1930 \mathrm{s.}^{38}$ Foreclosure, eviction, or bankruptcy were threats to a farm woman's family, but clearly they also threatened her traditional identity. That fear was apparent in the text of a radio address Edna Jones delivered in October 1934. "Woman's place is in the home,' it is said by those who are victimizing the common people at every opportunity. But if the farm home has been foreclosed and the farm woman has been evicted, then

36. Farm Holiday News, 15 May 1934. There is some evidence that women did participate at anti-foreclosure actions. Much more needs to be done on this important aspect of the Holiday. See Pratt, "Rethinking the Farm Revolts", 134, especially note 22 .

37. Minutes of the National Farmers' Holiday Association, 3 May 1934, Milo Reno Papers, Special Collections, University of Iowa Libraries, Iowa City. 38. Shover, Cornbelt Rebellion, 10; Bauer, "Farm Mortgagor Relief Legislation," 24. 
just where is her place? Her place is to stand shoulder to shoulder with her husband. For if he cannot save the home, then the mother and the family have no home:" 39

During the Iowa Farmers' Holiday Association meeting in Des Moines on May 21, 1934, the Ladies Auxiliary held its first convention. Besides listening to addresses by National FHA president Milo Reno, Iowa FHA president John Chalmers, and Iowa farm-labor editor and gubernatorial candidate Wallace Short, the women adopted by-laws and a constitution and elected officers. All eight officers whose names are provided are identified as "Mrs." Only one used her given name; the rest used their husband's first name. The majority of the women were married to county Holiday leaders. For example, board member Mrs. Lena Johnson was wife of the president of the Monona County Holiday, A. J. Johnson. ${ }^{40}$

The by-laws and constitution the auxiliary adopted clearly exhibit the ideologies upon which the organization was based and provide insight into the way its members interpreted their world and their female consciousness. The by-laws' eleven articles covered such topics as finance, elections, membership, and voting power. The auxiliary extended membership to "anyone engaged in the production of agricultural products and anyone who will pledge herself to support this program and the purpose therein declared." The "Purpose" was fourfold: to endorse the FHA and "cost of production," to "establish justice and apply the golden rule" by bringing farming up to the standard of other industries, to "arouse the public sentiment to the injus-

39. Farm Holiday News, 15 October 1934. The fact that Jones made a radio address is significant, although there are no other references to more addresses. Other Holiday leaders, especially Milo Reno, spoke on radio nearly every Sunday. While we cannot gauge Jones's audience or popularity, her command of that technology makes her leadership position comparable to that of Holiday men.

40. The women elected to the state board all came from the western Iowa counties of Monona, Shelby, Montgomery, Pottawattamie, and Harrison. Farm Holiday News, 1 June 1934. Mrs. Johnson was supportive of her husband's involvement and attended Holiday meetings in Monona County, but when I spoke to her daughters, neither recalled their mother telling them about any formal involvement in the Holiday or about attending meetings in Des Moines. Mrs. Nola Eskelsen, telephone conversation with the author, 14 October 1990; Mrs. Lavonne Woffington, telephone conversation with the author, 22 October 1990. 
tice of the agricultural problems," and to "educate ourselves in all civic and legislative matters and recognize the importance of voting at all elections." 41

The auxiliary's initial resolutions mimicked the earlier national resolution on the attacks upon women, but restated it even more forcefully. Foreclosures on farm homes and the eviction of farm families were their primary concern as they resolved "that we condemn these cowardly attacks upon the womenhood [sic] of the farms and go on record as pledging ourselves to take militant action, if necessary, to halt such acts and punish those responsible." The second resolution called for farm women to be able to secure modern conveniences such as electric lights and power. They declared further, "we shall support no candidate for state office who does not pledge himself to use every effort to make it possible for the women of the farms to enjoy the conveniences to which they are entitled." Again, these women stressed the importance of the farm home, the idea that farm women as a group were entitled to these benefits. Clearly, too, they viewed voting as an expression of power. Finally, they demanded that the system of distribution be removed from the hands of "international bankers." 42

The creation of a constitution and by-laws is important because it indicates that these women made claims. They claimed their citizenship as voters and their status and entitlement as farm women. Their agenda warranted serious consideration. Yet the question remains: what were the consequences of organizing around these specific claims, using these particular ideologies and a female consciousness? Temma Kaplan has noted the revolutionary potential of women with female consciousness. "A government that fails to guarantee women their right to provide for their communities according to the sexual division of labor cannot claim their loyalty." ${ }^{\prime 3}$

This "revolutionary potential" does not seem to reside within the ideological formation that the Ladies Auxiliary chose. For example, in 1935 the auxiliary fought a county unit plan for centralization of rural schools and battled against slot

41. Farm Holiday News, 1 June 1934.

42. Ibid.

43. Kaplan, "Female Consciousness," 560. 
machines. They also gathered en masse to protest unfair examination of eighth-grade students. ${ }^{44}$ At first glance, these targets do not appear to be fundamentally critical or revolutionary. Instead, they point to the auxiliary members' desire to protect their children from various threats and their willingness to nurture the children who would become the women and men who would correct the system. A fair, accessible education free from the corrupting influences of gambling fits in with this aim, one featured in many of the women's statements. Their ambition to influence school policy and regulate an activity that would normally be construed as an example of male privilege, such as gambling, could eventually place these women alongside other advocates of social purity. Kaplan may hope that women with female consciousness could revoke their loyalty to the government, but the continuing agenda of the Ladies Auxiliary points to their desire to reform rather than fundamentally critique. While the ideological basis they chose for their organization may have constrained some activities, it did allow them to organize around issues that threatened their values. We uncover more of the complexities of the Farmers' Holiday when we consider their voices.

SOME WOMEN, such as the members of the Ladies Auxiliary, played publicly visible roles in the Farmers' Holiday and left their actions, names, and editorials in newspapers. At the same time, many more women filled other roles as anonymous rankand-file activists. Those women and their actions are not yet visible. The extent to which women were involved in supporting and opposing the Holiday remains an intriguing question. When we know more about them, it will be possible to reconstruct the Holiday, taking into consideration the way gender relations informed its organization. Using the lens of gender illuminates other aspects of the Holiday as well. For example, focusing on the products targeted for the withholding action highlights the importance of women's productive labor on the farm and its connection to the Holiday.

The early Holiday withholding action did not allow any produce through, including eggs or poultry. The blockades

44. Farm Holiday News, 25 February and 25 April 1935. 
were relaxed after August 30, and the ban on eggs and poultry specifically was lifted. ${ }^{45}$ Why would Holiday leaders decide to lift the ban on these particular products? The importance of egg and poultry money to the family farm economy, and women's direct relation to these products, may help to provide an answer. Women's association with this critical aspect of the farm economy also helps to explain the ambivalence, outright hostility, and desperation some farm women felt toward the withholding action.

On family farms, women ran the egg and poultry operations and controlled the money or the bartering power that came from the exchange of their products. Deborah Fink has analyzed the gendered labor performed on the farm and the importance of egg and poultry production. She concludes that while men contributed indirectly and directly to farm income, "most of the routine household purchases of food and clothing and some of the religious, medical and social services were contracted and paid for by the women." ${ }^{46}$ Men were responsible for livestock, but chickens or poultry were rarely considered part of that category. Thus, when we look again at the Nelsons, who tried but failed to break through the Omaha blockade "to sell his chickens," it is clear that "his" chickens were more likely hers. The Nelsons' desperation illustrates how necessary that money was for their continued existence.

That was particularly true in 1932, when the sale of eggs and poultry yielded a better return for farmers than hogs and other farm products, though they still failed to meet the cost of production. An article in the Mapleton Press summarizing prices in September 1932 announced, "Poultry is Farm Bright Spot Now: Flock Returns are Close to Pre-War and Other Products are Far Below Level." The article continued, "Old Biddy is helping to 'keep the homefires burning on many Iowa farms.' ... Of the individual commodities, poultry sold for meat stood at 112 per cent, or 12 per cent above pre-war levels, and eggs at 85 per cent or 15 per cent below pre-war levels. The only other product higher than eggs was cattle at 94 per cent. September egg prices

45. Shover, Cornbelt Rebellion, 50; Mapleton Press, 1 September 1932.

46. Deborah Fink, Open Country Iowa: Rural Women, Tradition, and Change (Albany, NY, 1986), 60-61. 
were only 4 per cent below those of September, 1931." Another headline on the same page noted, "Hog Prices May Land Near Zero. ${ }^{47} \mathrm{~A}$ better understanding of this gendered division of labor would help us reassess the Farm Holiday more generally.

We also need to reassess women's "hidden labor" as farm laborers and housekeepers and how this labor enabled men to engage in the more noticeable activities of the Holiday movement. We may find that women assumed roles not typically labeled "activist," but which created the conditions necessary for the collective action to occur. Women may have increased the number of their responsibilities on the farm, or they may have made creative use of the products that they agreed to withhold from the market. Women may also have contributed to informing neighbors on the telephone about impending actions or raising consciousness about the Holiday through conversations in town. Some working women were also active in support of the Holiday. In an article about the Holiday for Scribner's Magazine, Josephine Herbst, a native of Sioux City, quoted a farmer who claimed, "The telephone girls are with us, they put the calls through. We can rouse the whole countryside in fifteen minutes. ${ }^{\prime 48}$ Although the farmer did not say so explicitly, phone operators may have been vitally involved in the quick action necessary to call out an emergency picket or to gather Holiday participants to stop a sale. Generally, those acts committed publicly are called "direct" action; those acts behind the scenes are defined as more "indirect" action. Because women's work probably contributed directly to men's ability to perform Holiday work, the split between "direct" and "indirect" action should be reconsidered.

No matter what divided farm women and men politically, the Farmers' Holiday must have been a topic of conversation at the dinner table, during chores, or in bed at night. Married couples were not leading lives of "separate spheres" in the Midwest in the $1930 \mathrm{~s} .{ }^{49}$ There were risks to picketing or running a block-

47. Mapleton Press, 3 November 1932.

48. Josephine Herbst, "Feet in the Grass Roots," Scribner's Magazine 93 (January 1933), 48.

49. Linda K. Kerber, “Separate Spheres, Female Worlds, Woman's Place: The Rhetoric of Women's History," Journal of American History 75 (1988), 9-39. 
ade; there were bills to pay, kids to feed, livestock to be marketed or withheld, and decisions to be made. Women probably negotiated those decisions. Similar negotiations may have occurred over women's attendance at meetings or picket line parades, or their membership in the auxiliary.

Uncovering those private conversations is difficult or impossible, but considering that they might have occurred creates new questions. How did constructions of femininity and masculinity affect membership, organizational structures, and choice of tactics? Who could attend meetings, and who was most likely to speak? How and why were women organized separately in 1933, and what facilitated the women's consciousness that inspired them? The entrance of a formal women's organization, like any other formal organization, marks an important point in a social movement, and bears serious consideration as part of the Farmers' Holiday. Understanding why many women resisted the Holiday is equally important. In general, considering how women supported or opposed the Holiday should change the way we analyze the movement. If the Holiday is considered an "engendered" phenomenon, if women's participation, strategy, labor, opposition, or absence is considered, it will force us to reconceptualize the formation and progression of this and other agricultural grass-roots movements. 
Copyright of Annals of Iowa is the property of State of Iowa, by \& through the State Historical Society of Iowa and its content may not be copied or emailed to multiple sites or posted to a listserv without the copyright holder's express written permission. However, users may print, download, or email articles for individual use. 